\title{
Sustainable Industrial Community
}

\author{
Hala Omar, Salah El-Haggar \\ Mechanical Engineering, The American University in Cairo, Cairo, Egypt \\ Email: halaomar@aucegypt.edu
}

How to cite this paper: Omar, $H$. and El-Haggar, S. (2017) Sustainable Industrial Community. Journal of Environmental Protection, 8, 301-318.

https://doi.org/10.4236/jep.2017.83023

Received: January 28, 2017

Accepted: March 24, 2017

Published: March 27, 2017

Copyright (c) 2017 by authors and Scientific Research Publishing Inc. This work is licensed under the Creative Commons Attribution International License (CC BY 4.0).

http://creativecommons.org/licenses/by/4.0/ cC (i) Open Access

\begin{abstract}
Nowadays, the style of living that significantly depends on consumption of resources and over consumption patterns, tremendous increase in population, urbanization and industrialization resulted into generation of huge amounts of industrial wastes. Many environmental problems are facing industrial areas, especially in developing countries, due to poor industrial hazardous waste management. In order to reduce the effect of industrial waste on the environment and to reach sustainable development, countries have developed and reinforced several environmental protection laws and regulations. Yet, the waste disposals via incineration and/or landfilling according to cradle-to-grave concept require high capital, high running costs and are seen by industries as a barrier for further industrial development. Most importantly, disposals of waste deplete natural resources causing them to be unsustainable. Hence, various concepts and strategies have been suggested to promote industrial sustainability. The aim of this paper is to present different concepts and practices including Cradle-to-Cradle approach, Cleaner Production, Industrial Ecology, EcoIndustrial Park and Environmentally Balanced Industrial Complex described in literature that help develop a successful sustainable industrial community and reach zero pollution. These concepts are illustrated via case studies. Moreover, this paper tackles the challenges facing industrial areas in Egypt and emphasis on the imperative need for considering sustainable industrial community.
\end{abstract}

\section{Keywords}

Industrial Waste, Sustainable Industrial Community, Cradle-to-Cradle, Cleaner Production, Eco-Industrial Park, Environmentally Balanced Industrial Complex, Zero Pollution

\section{Introduction}

Industrialization and growth in the resource consumptions coupled with the rapid increase of population size and urbanization have placed a relentless pres- 
sure on the scarcity of natural resources and disposal of waste generated. All industries have been an open system of material flow. In fact, natural resources are extracted, consumed to produce goods; once these materials worn out, they are disposed of either through incineration and/or landfill. These practices not only require high capital and running costs, but also contribute to the depletion of natural resources [1] [2] [3] [4]. Since the emergence of the concept of sustainability during the United Nations Conference on Human Environment in 1972, there has been growing awareness that the natural resources are finite leading to increasing calls for development of sustainable communities [5] [6] [7]. The Publication of Brundtland Report, "Our Common Future", by the World Commission on Environmental and Development (WCED) defined sustainable development as the "development that meets the needs of the people today without compromising the ability of future generations to meet their own needs" [8]. People realize that sustainable development cannot be achieved without the involvement of policy makers, environmentalists, society, and business community.

In order to reduce the effect of industrial waste on the environment and to reach sustainable development, countries have drafted and adopted several environmental protection laws and regulations. Yet, the waste treatment and disposal techniques and environmental protections procedures are seen by industries as a burden and a barrier to further industrial development, as they are very expensive activities. Therefore, it is crucial to develop sustainable solutions to industrial waste problem. Three main concepts have been suggested and if properly implemented, they can be used to develop a sustainable industrial community and reach zero pollution as summarized in Figure 1. The first concept is Cleaner Production (CP) that aims to prevent waste generation at the source through waste reduction techniques, recycling and/or process modification. The second concept is Industrial Ecology (IE), of which objective is to utilize waste of one industry as the raw material of another industry. Based on IE concept, several Eco-industrial Parks (EIP) have been developed in which any waste is either reused or re-treated to reach cyclic flow of material and prevent waste generation. The third concept is Environmentally Balanced Industrial Complex (EBIC) designed to locate compatible industries close to each other that can utilize each

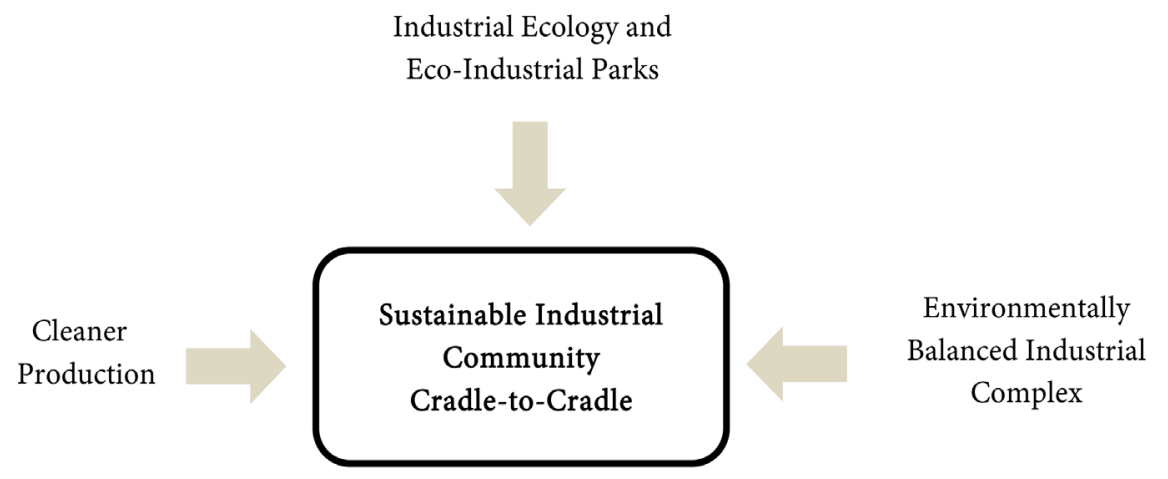

Figure 1. Strategies to achieve sustainable industrial community. 
other waste. The main advantage of adopting these concepts is to minimize and/or eliminate the cost of raw material, transportation, storage, and waste disposal and treatment. In this paper, different concepts and practices described in the literature for the development of a successful sustainable industrial community are presented. Also, this paper aims to persuade decision makers, society and entrepreneurs of the imperative need of developing a sustainable industrial community in Egypt and clarifies the challenges faced in this regard.

\section{Cradle-to-Cradle Approach}

Industry has been following a linear model known as "Cradle-to-Grave" illustrated in Figure 2. Resources are transformed into goods, which are thrown away or disposed of in a "grave" at the end of their lives.

Ecological impacts and long-term effects have been overlooked in the name of making profits. Some industrial practices unintentionally cause environmental problems. Many companies design products with "built-in-obsolescence" for a limited period of time and then become obsolete or unfashionable. Companies pursue this strategy to encourage their client to buy new version or model of the

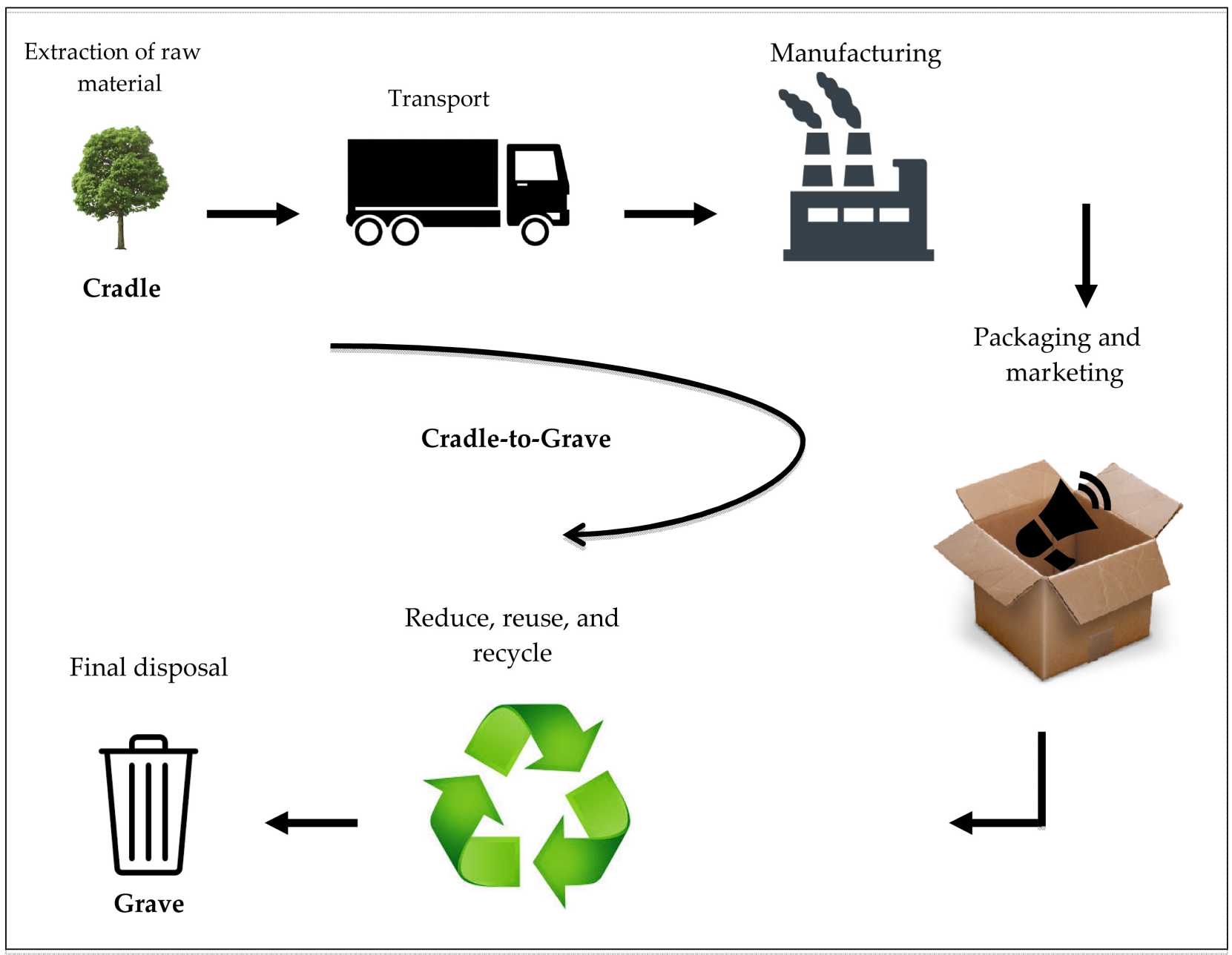

Figure 2. Cradle-to-grave approach. 
product. It is often cheaper to buy a new product than to repair it. Additionally, portion of material is just designed for packaging and aesthetic reasons; in other words, it becomes waste almost immediately. Although these practices help companies make a lot of profits, they encourage people to throw away a lot of material and generate a lot of waste.

The industrial sector generates different types of waste including: 1) plastics and paper used for packaging, 2) organic material from food industry, 3) dust from cement, marble and granite industries, 4) glass, 5) slag and foundry sand from smelters or foundries ... Industries usually deal with these wastes via pollution control, treatment and disposal through incinerators and/or landfill. Incineration is a process in which solid waste is burnt and converted to ash. The main benefit of incineration is to considerably reduce the amount of solid waste. Also, the solid waste and/or ash produced from incineration are usually landfilled. Landfilling process requires durable and puncture resistant material to be used as a liner, usually polyethylene, high-density polyethylene and polyvinyl chloride. It also needs coverage for the landfill, a leachate collection system, biogas collection system as well as a storm water drainage system. The main disadvantage of incineration and landfilling processes is that they require high capital, high running costs, and most importantly they deplete natural resources causing them to be unsustainable [1]. Consequently, several approaches have emerged and started to be used in industrial sector to reach sustainable development.

McDonough and Braungart proposed to shift to cradle-to-cradle where waste is used for production of other goods. This concept is based on production of goods that can be infinitely circulated in industrial cycles. McDonough and Braungart expresses their intention to move towards cradle-to-cradle approach by making the paper of their book, entitle "Cradle-To-Cradle: Remaking the way we make things", out of plastic resins and inorganic filler instead of the traditional paper made by using wood and depleting trees [9]. This synthetic paper could be reused to make paper or other products. Based on this approach, products should be made of material that can be infinitely reused while maintaining its properties. This closed loop cycle of material flow, illustrated in Figure 3, will not only minimize the amount of waste generated and save the environment, but also ensures the continuous availability of high quality material.

\section{Cleaner Production}

In order to reach sustainability and approach zero pollution in industrial sector, the concept of Cleaner Production (CP) was developed by United Nations Environment Program (UNEP) in 1989 [10]. The aim of CP is to prevent waste generation at the source. This is achieved by applying different techniques illustrated in Figure 4.

The first practice is to reduce waste from the source through 1) good housekeeping by optimizing process and eliminating all leakages and/or any practice that results into unnecessary losses, 2) changing production process by modifying the process itself, changing the equipment used, substituting raw material 


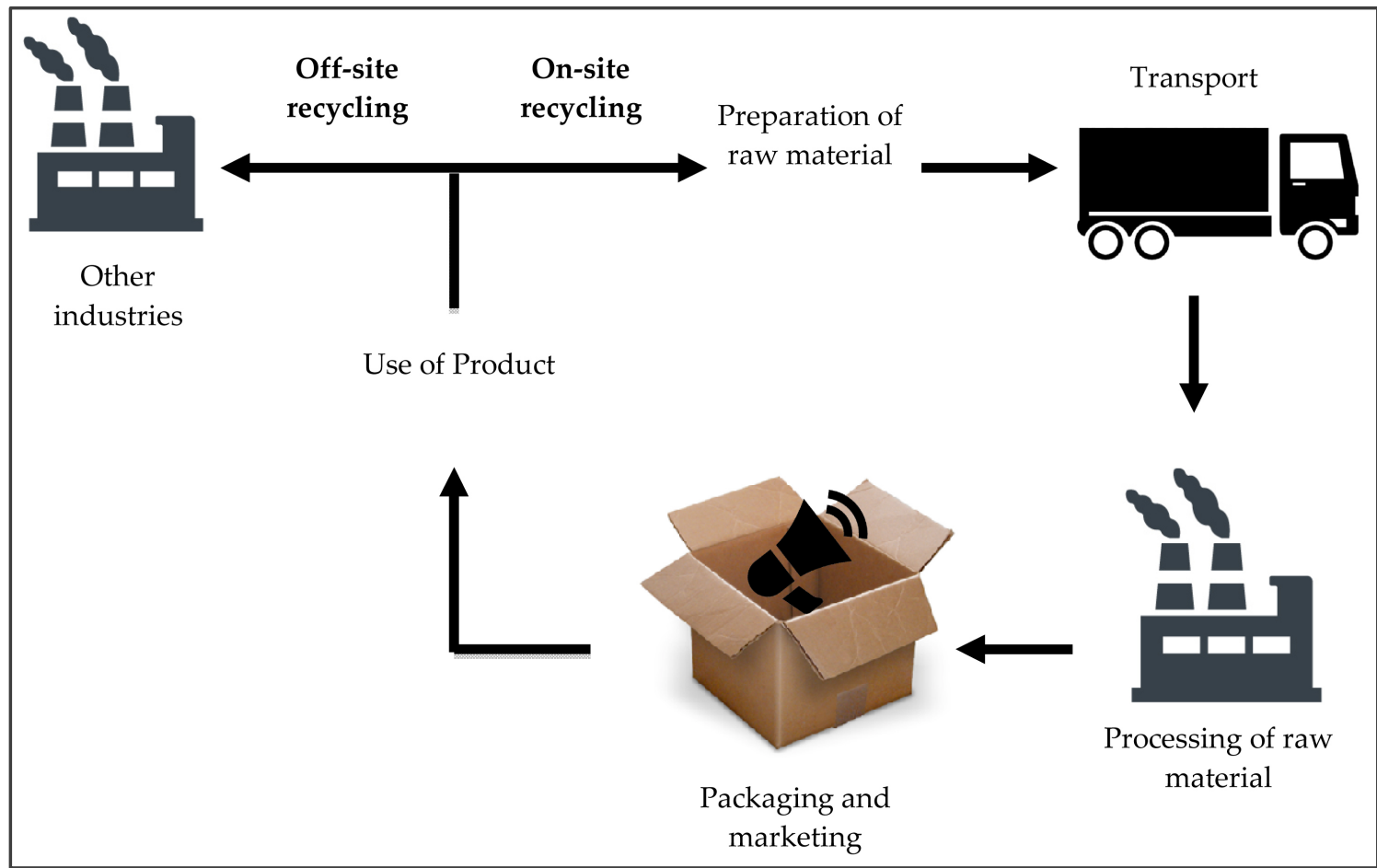

Figure 3. Cradle-to-cradle approach.

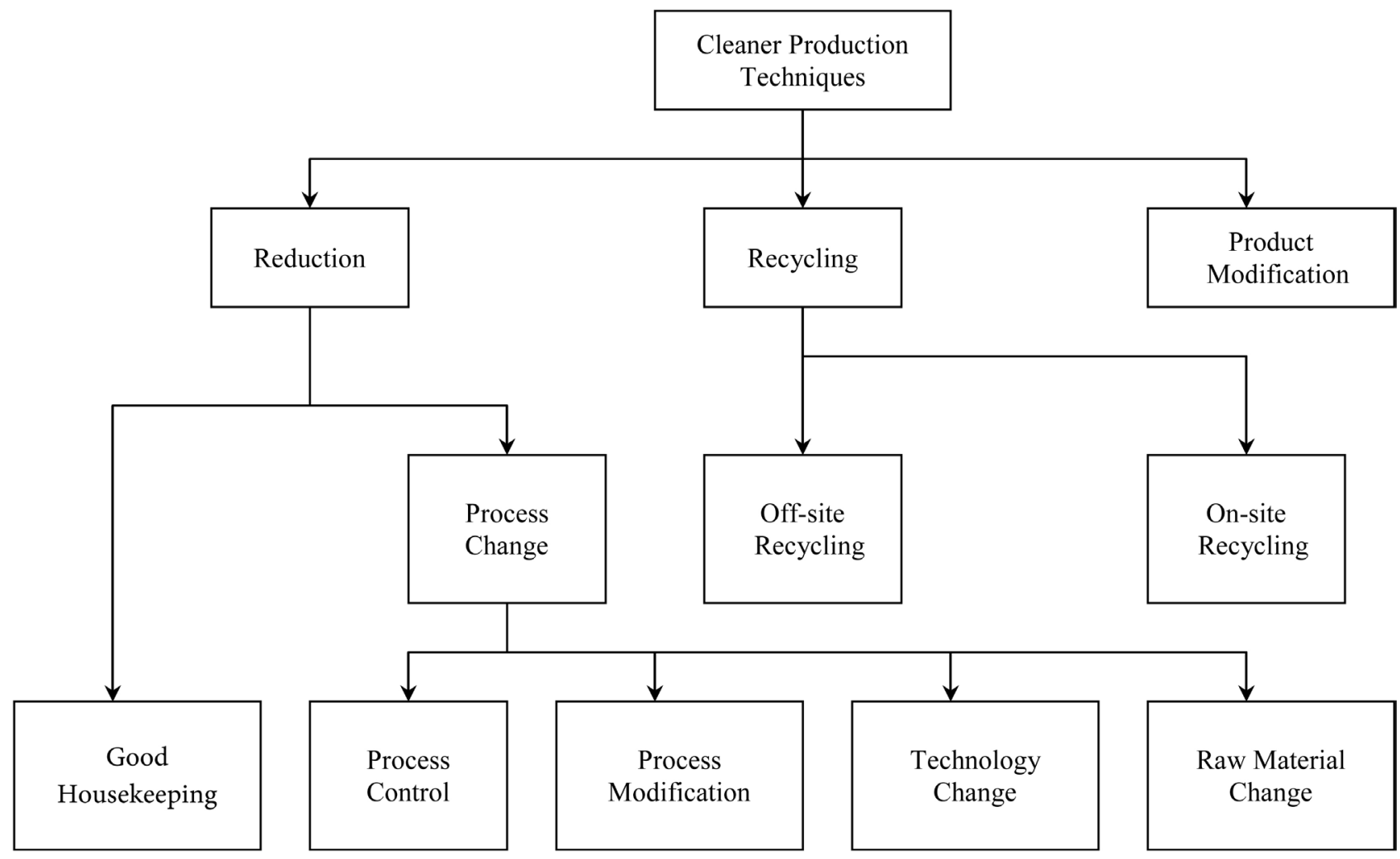

Figure 4. Cleaner production techniques [2].

used for another one that is less harmful to the environment, and implementing robust process control to ensure continuous and efficient monitoring and main- 
tenance of optimum production conditions to minimize waste generation, save energy, water and raw material as well as increase process efficiency. The second method of CP is to recycle wastes material either inside the same factory to replace raw material (on-site recycling) or give waste materials to another party that recycle it and sell it to another industry (off-site recycling). The last technique is product modification, which involves changing the design of the product to use fewer raw materials and/or less energy to eliminate emissions and hazardous industrial wastes [1] [11].

\section{Cleaner Production Case Study in Egypt}

Sila Oil Company is located in Fayoum in Egypt. This company extracts oil from oil-bearing seeds. The extraction process steps are summarized in Figure 5.

Industrial audit of factory took place and three major problems were identified including 1) steam lines were not properly insulated causing around 34 ton/day of steam losses, 2) broken seeds and hulls were treated as waste instead of using it in the process, and 3) $2 \%$ - 5\% of total fuel consumption leak during the delivery and transfer in the receiving area.

Several cleaner production techniques were implemented as follows:

1) Good Housekeeping: in this case a preventive maintenance program was

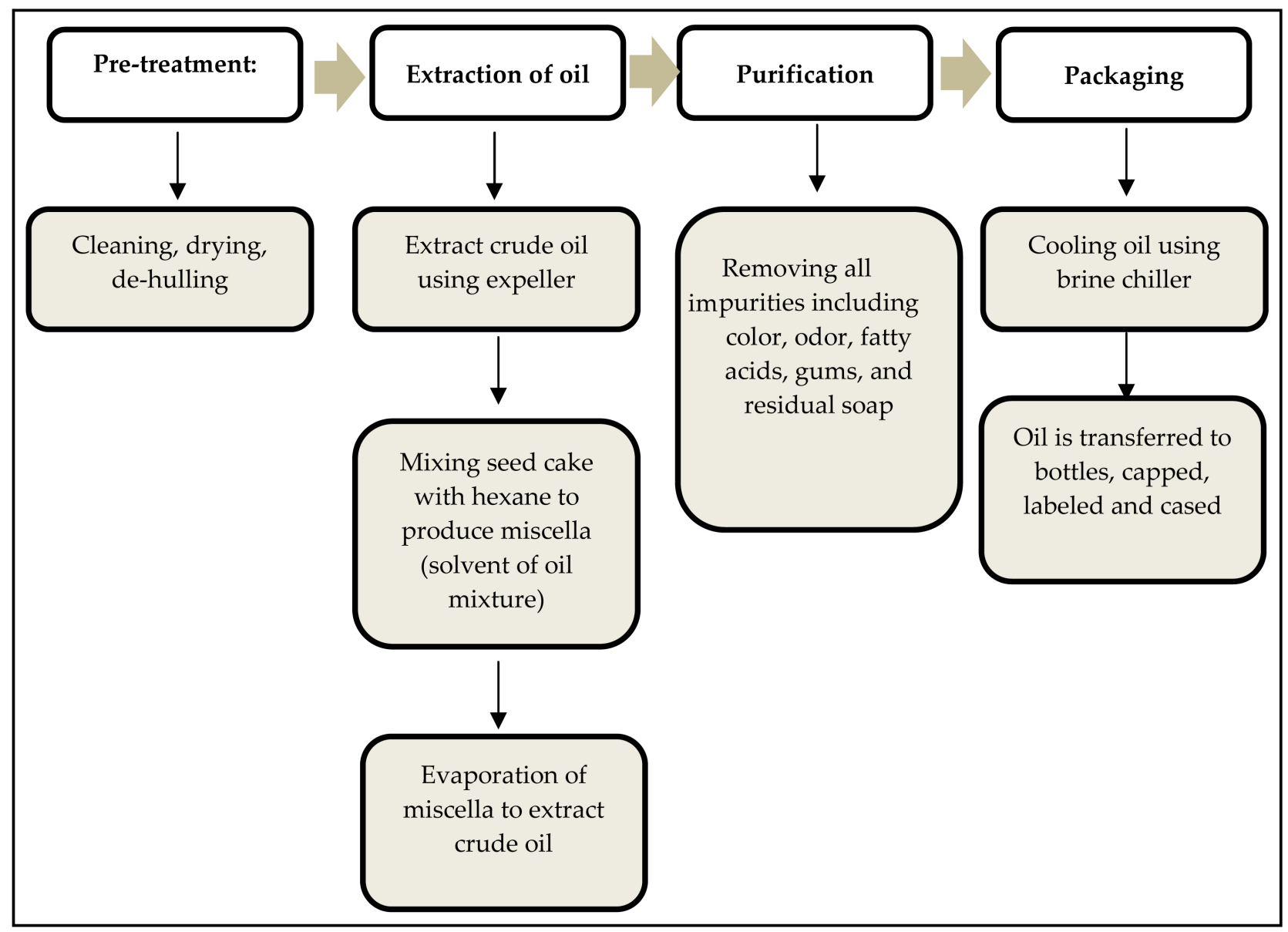

Figure 5. Oil extraction process from oil bearing seeds in Sila Oil Company. 
implemented involving servicing of the expeller and modification of the packing of the cooling tower.

2) Process Modification: the production process was modified by converting the path of the recycled sunflower seed fins from the expeller to the extraction plant. Thus, the capacity of the expeller increased.

3) Material Substitution: fatty acids were removed using solid caustic soda, which was highly corrosive. This material was replaced by caustic soda solution this technique resulted into use of less harmful material as well as decrease in cost of fatty acids removal process.

Table 1 summarizes the cost/ benefit resulting from implementing $\mathrm{CP}$ techniques in Sila Oil Company.

In conclusion, it was found that cleaner production techniques resulted into more environmentally friendly process; better product quality as well as financial savings [2].

Table 1. Cost/benefit summary [2].

\begin{tabular}{|c|c|c|c|c|}
\hline $\begin{array}{l}\text { Factory } \\
\text { unit }\end{array}$ & Action & $\begin{array}{c}\text { Capital/operating } \\
\text { cost }(\$)\end{array}$ & $\begin{array}{c}\text { Yearly } \\
\text { savings (\$) }\end{array}$ & $\begin{array}{c}\text { Payback } \\
\text { period } \\
\text { (month) }\end{array}$ \\
\hline Refinery & Use of liquid caustic soda & None & 43,860 & Immediate \\
\hline Steam & Upgrade system network & 4260 & 97,010 & $<1$ \\
\hline Receiving & Recovery of broken seeds & 1580 & 81,270 & $<1$ \\
\hline $\begin{array}{l}\text { Preparati } \\
\text { on }\end{array}$ & Reuse of fines & 1750 & 21,050 & 1 \\
\hline All & $\begin{array}{c}\text { Preventive maintenance } \\
\text { program }\end{array}$ & 2630 & 5260 & 6 \\
\hline
\end{tabular}

\section{Industrial Ecology}

Another approach known as "industrial ecology" came to life to reach sustainable development. The concept of industrial ecology was first defined by Frosch and Gallopoulos in 1989 as a system in which "energy and materials is optimized, waste generation is minimized, and the effluents of one process [...] serve as the raw material for another" [12]. In 1994, White introduced the socio-economic aspect of industrial ecology "the study of the flows of materials and energy in industrial and consumer activities of the effects of these flows on the environment, and of the influences of economic, political, regulatory and social factors on the flow, use and transformation of resources" [13]. Later in 2006 Allenby defined industrial ecology as "a system-based, multidisciplinary discourse that seeks to understand emergent behavior of complex integrated human/natural systems" [14]. The main aim of industrial ecology is to solve environmental issues while maintaining economic growth. This concept is based on mimicking the natural ecosystem cycle in the industrial system. In the natural ecosystem, plants grow by taking energy from sunlight and nutrients from soil. These plants become the food of herbivore, which in their turn become the food for carnivore. 
Then bacteria and other organism take up nutrients from all dead matters and produce molecules to feed new lives. In order to understand this analogy, "think of the organism as being the industrial process or the set of industrial processes that lead to a particular product or product family and of the ecology being the network of all industrial processes as they may interact with each other and live of each other" [15]. In natural eco-system waste generated is biodegradable and recycled to close the loop, while in industrial system waste generated is non-biodegradable and accumulates and causes problems. In an industrial ecosystem the waste of one industry serves as the raw material of another industry [7]. Industrial ecology promotes cyclic flow of material rather than linear flow of material [16]. Industrial ecology has several environmental and economic advantages. In fact, material used in industry comes from the waste of other industries thus the cost of raw material decreases and waste issues are solved. As waste is viewed as a valuable resource, the cost of waste disposal is minimized. Another advantage is that "niche industries" can start growing and use and/ or sell waste from main industries [7]. This will allow minimizing the waste generated from industries and maximizing the reuse of material and energy. Industrial Ecology; therefore, promotes sustainable industries in a sustainable society [17].

\section{Eco-Industrial Park}

According to the eco-industrial approach, Eco-Industrial Park is the ideal model of an industrial community. In this park any waste is either reused or re-treated to reach cyclic flow of material and ensure sustainable development. Eco-industrial Parks are a direct application of the industrial ecology approach. Many efforts were done to study eco-industrial parks. Indeed, there are a large number of literatures on this subject and several definitions of eco-industrial parks were proposed as summarized in Table 2.

From these definitions, it can be concluded that the aim of EIP is to cluster different industries in one location in order to minimize energy and material waste. Figure 6 illustrates economic, environmental, social government benefits of EIPs.

Many researches indicate that sustainable development of the economy can be promoted via implementation of a successful eco-industrial park [6] [18]-[23].

\section{Examples of EIPs}

The most well-known EIP is Kalundborg in Denmark, which started to develop in 1960. Although it was not designed to be an EIP, it is now a model against which all EIPs are judged. Kalundborg symbiosis compromises of five core participants including Asnaes a power plant, Statoil an oil refinery, Novo Nordisk (a pharmaceutical company), the City of Kalumdborg, and Gyproc (a manufacturer of wallboard). Figure 7 summarizes the partnership sequence of evolution and the material and energy flow in Kanlundborg.

As illustrated in Figure 4, in Kalundborg different industries feed on each other's waste and transform them into useful products. As explained by Gertler 
Table 2. Definitions of eco-industrial park.

\begin{tabular}{|c|c|}
\hline Eco-Industrial Park Definitions & References \\
\hline $\begin{array}{l}\text { "A large tract of land, sub-divided and developed for the use of several firms } \\
\text { simultaneously, distinguished by its shareable infrastructure and close proximity of } \\
\text { firms." }\end{array}$ & [24] [25] \\
\hline $\begin{array}{l}\text { "An eco-industrial park is an industrial system which conserves natural and } \\
\text { economic resources; reduces production, material, energy, insurance and } \\
\text { treatments costs and liabilities; improves operating efficiency, quality, worker } \\
\text { health and public image; and provides opportunities for income generation from } \\
\text { use and sale of wasted materials." }\end{array}$ & {$[25][26]$} \\
\hline $\begin{array}{l}\text { "An eco-industrial park is a community of manufacturing and service businesses } \\
\text { seeking enhanced environmental and economic performance through } \\
\text { collaboration in managing environmental and resources issues including energy, } \\
\text { water and materials. By working together, the community of businesses seeks a } \\
\text { collective benefit that is greater than the sum of the individual benefits each } \\
\text { company would have realized if it optimized its individual interests." }\end{array}$ & $\begin{array}{c}{[6][25]} \\
{[27]}\end{array}$ \\
\hline $\begin{array}{l}\text { "A community of businesses that cooperate with each other and with the local } \\
\text { community to efficiently share resources (information, materials, water, energy, } \\
\text { infrastructure and natural habitat), leading to economic and environmental quality } \\
\text { gains, and equitable enhancement of human resources for the business and local } \\
\text { community." }\end{array}$ & [25] \\
\hline $\begin{array}{l}\text { "An industrial system of planned materials and energy exchanges that seek to } \\
\text { minimize energy and raw materials use, minimize waste, and build sustainable } \\
\text { economic, ecological and social relationships." }\end{array}$ & [25] \\
\hline $\begin{array}{l}\text { "An eco-industrial park or estate is a community of manufacturing and service } \\
\text { businesses located together on a common property... The goal of an EIP is to } \\
\text { improve the economic performance of the participating companies while } \\
\text { minimizing their environmental impacts. Components of this approach include } \\
\text { green design of park infrastructure and plants (new or retrofitted); cleaner } \\
\text { production, pollution prevention; energy efficiency; and intercompany partnering. } \\
\text { An EIP also seeks benefits for neighboring communities to assure that the net } \\
\text { impact of its development is positive." }\end{array}$ & {$[6]$} \\
\hline $\begin{array}{l}\text { "A selective collection of compatible industrial plants located together in one area } \\
\text { (complex) to minimize both environmental impact and industrial production } \\
\text { costs. These goals are accomplished by utilizing the waste materials of one plant as } \\
\text { the raw materials for another with a minimum of transportation, storage and raw } \\
\text { material preparation." }\end{array}$ & [2] [4] \\
\hline
\end{tabular}

the basis for the Kaludborg system is "creative business sense and deep-seated environmental awareness", and "while the participating companies herald the environmental benefits of the symbiosis, it is economic that drives or thwarts its development" [28].

\section{Environmentally Balanced Industrial Complex}

Similar to the idea of EIPs, Nemerow and Dasgupta introduced the concept of Environmentally Balanced Industrial Complex (EBIC) in 1986 as a method to reach zero pollution. Nemerow defined EBIC to be "a selective collection of compatible industrial plants located together in one area (complex) to minimize 


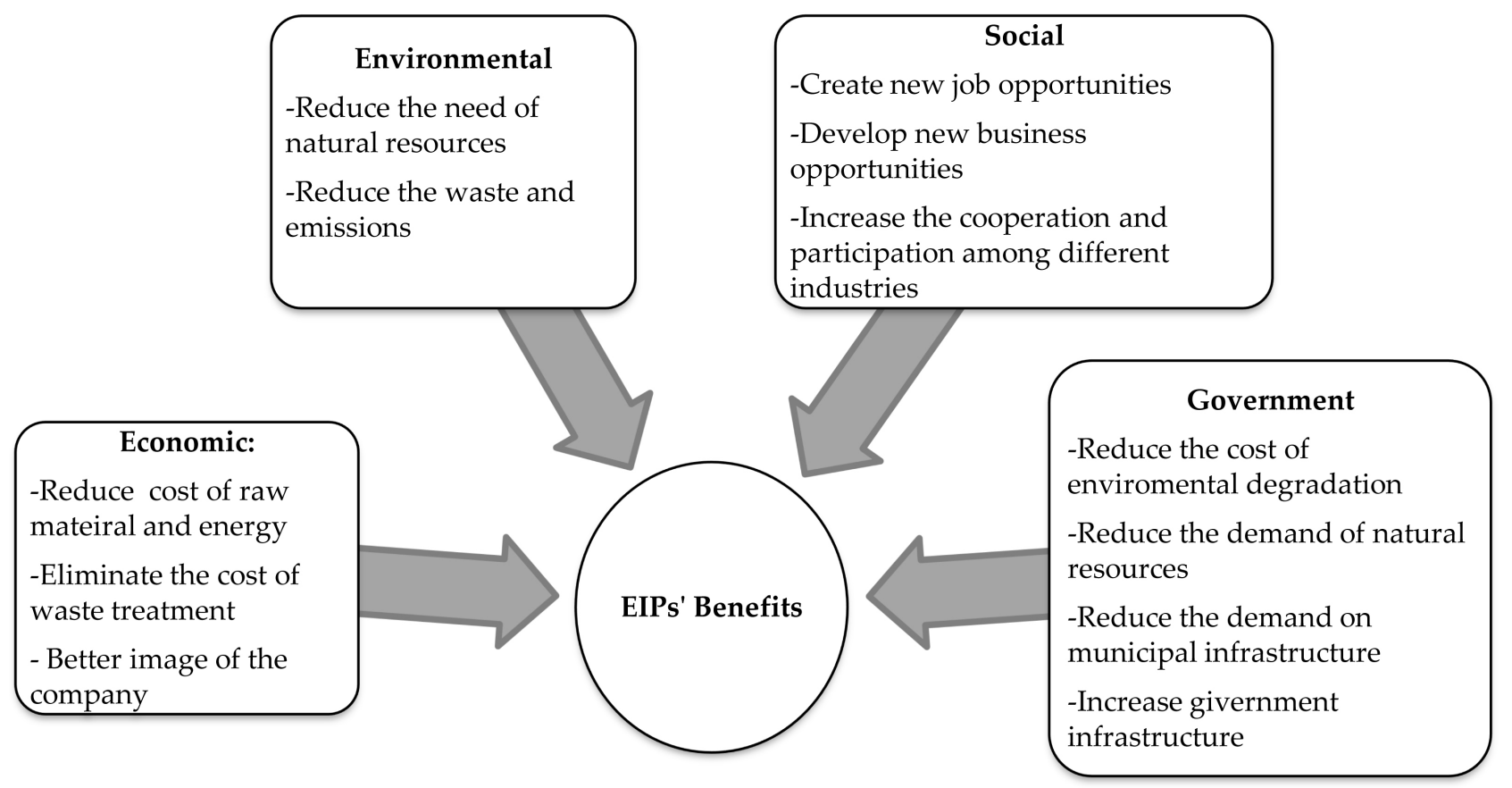

Figure 6. Benefits of EIPs.

both environmental impact and industrial production costs" [4]. Unlike EIPs, the EBIC is an area that is designed to locate compatible industries close to each other. According to Nemerow, EBICs are suitable for large waste consuming and waste producing industries. The goal of this designed complex is to utilize the waste of some industries as the raw material for others; thus minimizing the cost of raw material as well as the cost of transportation, storage, and waste disposal and treatment. It is important to study the physical distance between the chosen industries, the economics of joining the industries as well as degree of compatibility of waste material to be used as raw material before matching the industries.

Several EBICs were investigated and proposed including sugarcane complexes, tannery complexes, textile complexes, pulp and paper mill complexes, fertilizer-cement complexes, fossil fuel power plant complexes, steel mill fertilizer-cement complexes, cement lime, and power plant complexes [4].

\section{Case Study: Environmentally Balanced Sugar Cane Refinery Complex}

The manufacturing process of sugar consists of several steps. First the sugar cane stalks are chopped into small pieces that are then crushed to extract juice. From this operation juice is extracted and solid fibrous residue of canes known as bagasse, are left out. Afterwards, extracted juice enters a boiler room where lime is added to precipitate insoluble sugars. The precipitate is filtered to form a filter cake called cachaza. Then the juice is thickened in evaporators, which is then boiled to form raw sugar crystals. The process results into crystalline brown sugar and molasses as well as two types of wastes bagasse and cachaza. Usually, 


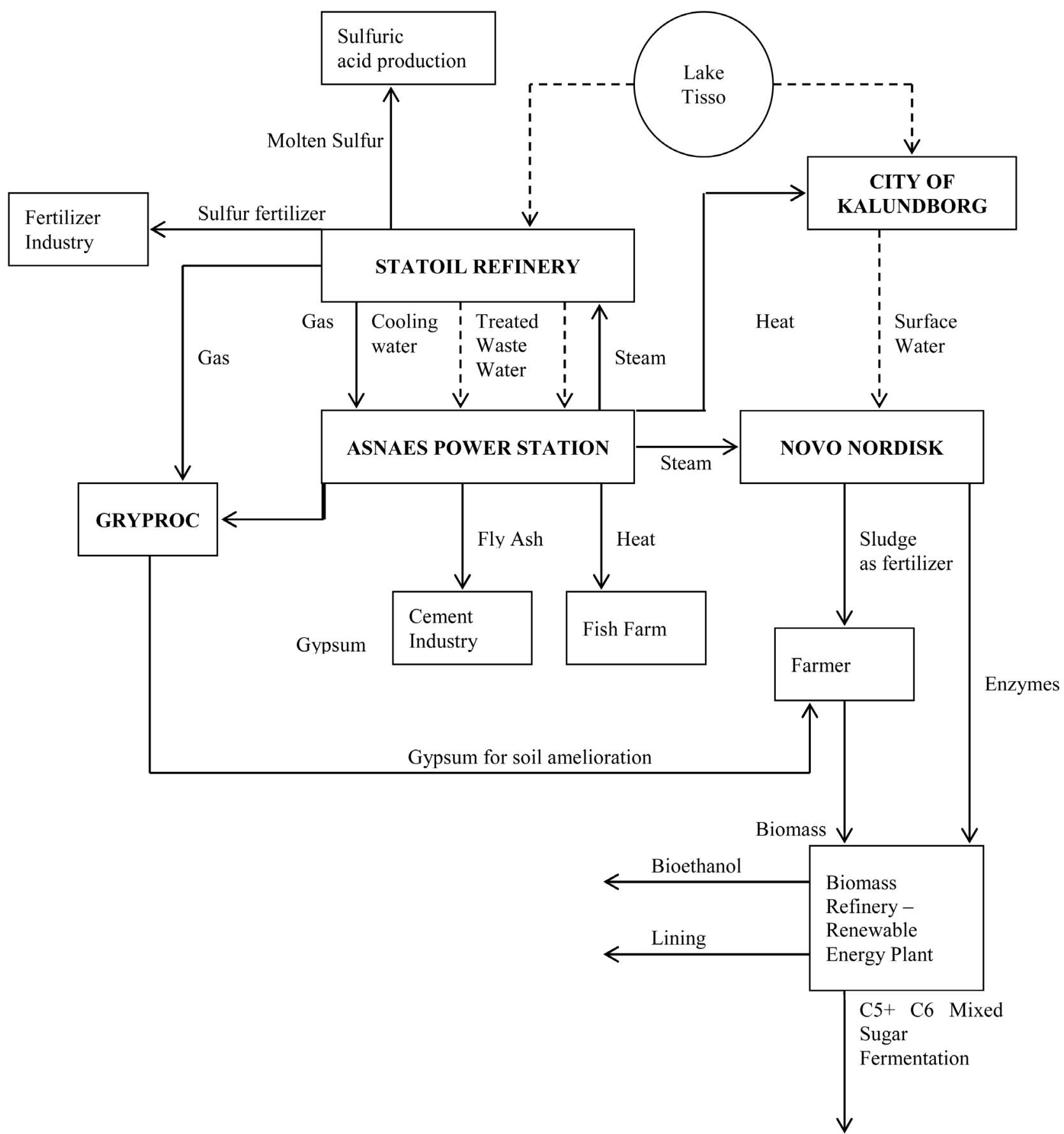

Figure 7. Kanlundborg eco-industrial park.

bagasse is burnt and used as a source of fuel to the boilers operated at sugar mills. Yet it is not a clean fuel and requires special furnaces to operate efficiently and also requires installation and maintenance of scrubbers to clean emission. On the other hand, cachaza is disposed of in lagooning or landfilled causing water and land pollution. To make the sugarcane industry sustainable, the production process residues and by-products have to be treated as raw material for other industries instead of being disposed of. Its wastes, residues and by-products should not be burned or disposed of but should be rather treated as raw material 
for other industries.

Therefore, Nemerow and Dasgupta proposed the development of sugarcane refinery-based environmentally balanced industrial complex shown in Figure 8. The core of this complex is an anaerobic digester, which treats the main residues; bagasse and filter cake. The four major products of the complex are: refined sugar, electrical energy, molasses and alcohol (optional), in addition to fermentation mash, digested and filtered sludge, digester gas, and steam [29] [30].

The refinery produces 1000 tons of sugarcane and results in a generation of about 270 tons of bagasse and 34 tons of cachaza.

The proposed refinery has many advantages including [29]:

- Steam required in the production is replaced by burning bagasse.

- The remaining bagasse and cachaza waste products are used as feeds for anaerobic digester.

- The anaerobic digester produces around $12,300 \mathrm{~m}^{3}$ of gas (mainly methane), 36 tons of filter cake and filtrate. Filtrate is re-used in the digester to enhance the digestion process.

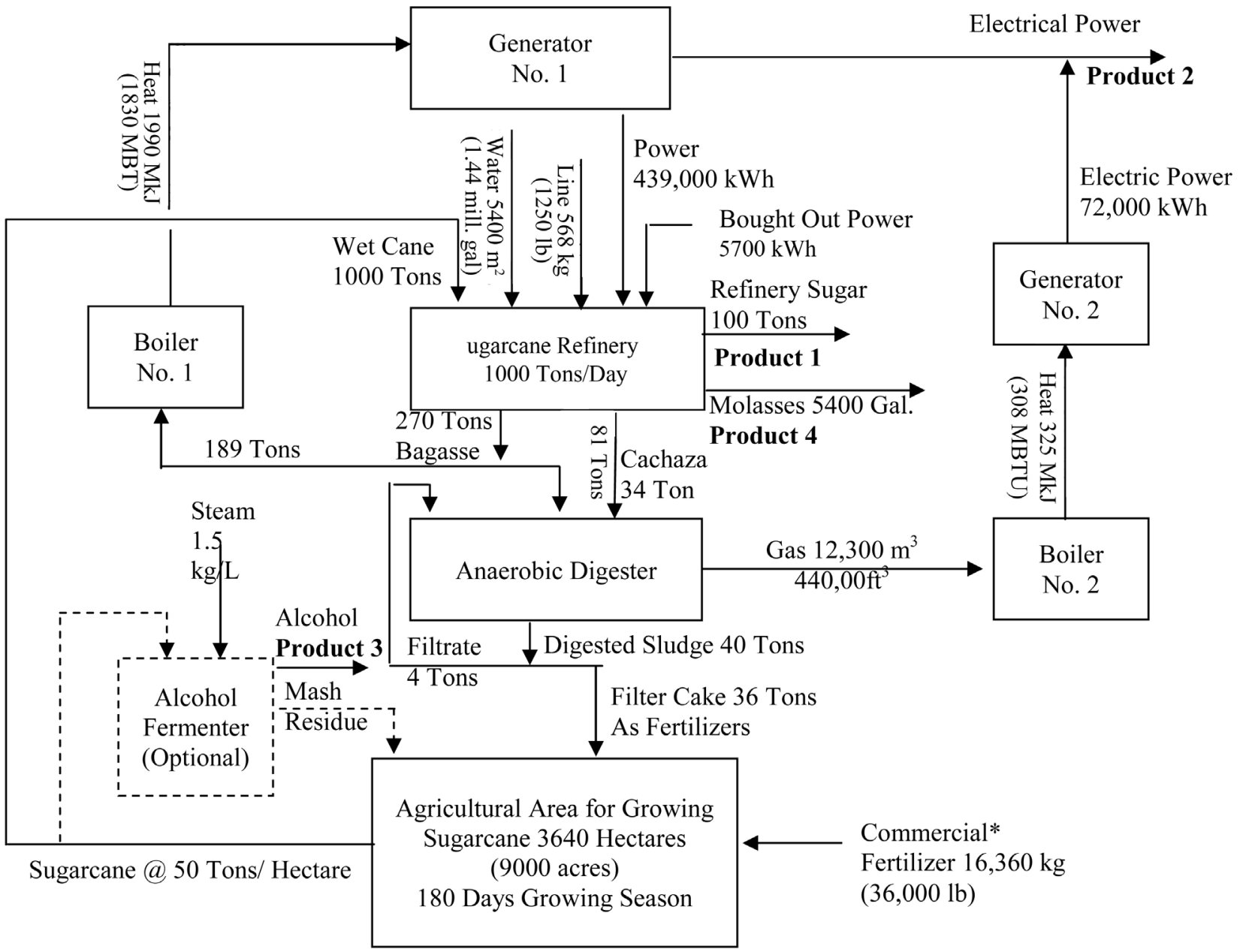

Figure 8. Sugarcane refinery-based environmentally balanced industrial complex proposed by nemerow and dasgupta [29]. ${ }^{*}$ Assuming no use of filter cake and marsh residue. 
- $325,000,000 \mathrm{~kJ}(308,000,000 \mathrm{Btu})$ of steam energy are produced from burning the gas in Boiler No. 2. This steam can then be used in the refinery itself or can be used to produce an estimate of $72,215 \mathrm{kWh}$ of electricity, which can be used in the refinery or sold as a product outside the complex.

- Filter cake mixed with commercial fertilizers is used as fertilizer to replace a portion of the commercial fertilizer needed in the fields to grow the cane.

- Cane can be used to produce alcohol via fermentation process. It is estimated that four pounds of cane can produce one liter of alcohol.

- The residues of alcohol fermentation process can be used as fertilizers in the field.

The mash residue from the alcohol fermenter can also be used as supplemental fertilizer for the sugarcane fields, decreasing the amount of commercial fertilizer required to be purchased from outside the complex.

Another sugarcane complex was proposed by El-Haggar [2] to suite Egyptian social and environmental norms as illustrated in Figure 9. In this complex the bagasse and is mixed with filter cake rich which is rich in fat and wax and used as binding material. The mixture is compressed at high temperature to form density packed briquettes. The resulting briquettes have a calorific value of $15,000[\mathrm{~kJ} / \mathrm{kg}]$, which make them suitable to be used as a fuel for boiler [2]. Also the boiling process results into precipitation of ash, which is proposed to be used as fertilizer.

Nakhla and El-Haggar [31] proposed another complex to close the loop of sugarcane industry in Egypt shown in Figure 10. There are two main open

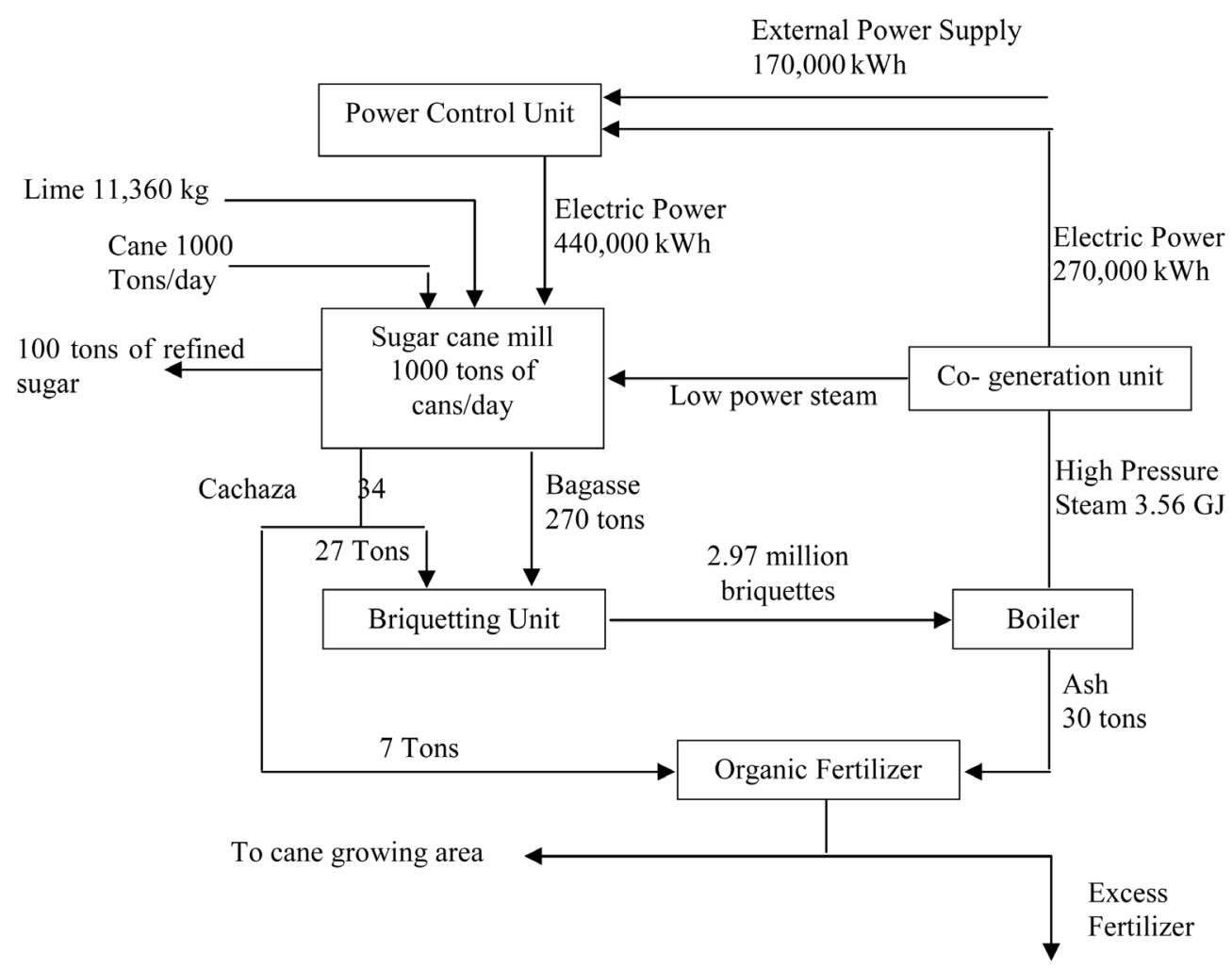

Figure 9. Sugar cane-briquettes-fertilizer complex proposed by El-Haggar. 


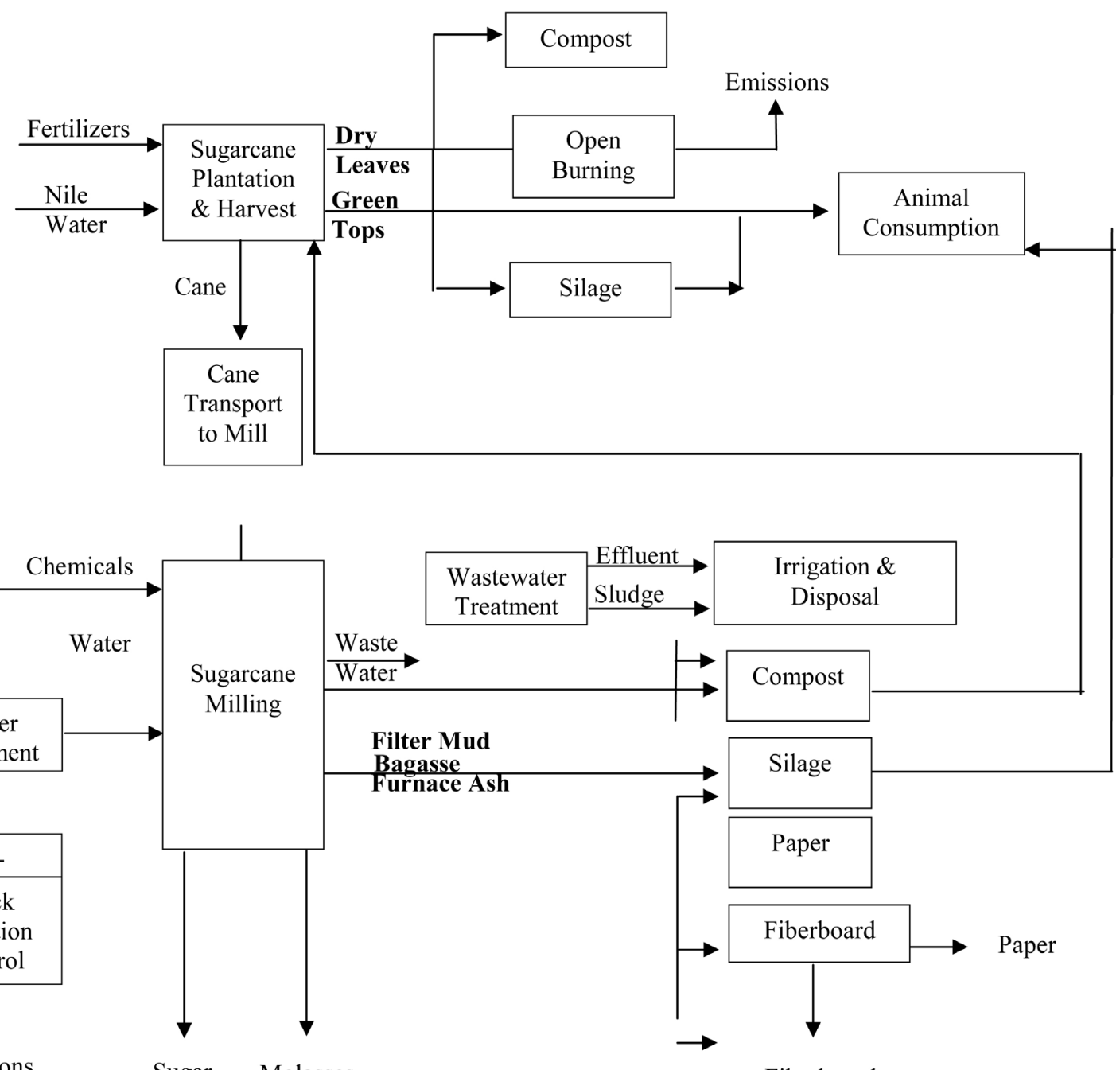

Emissions

Sugar Molasses

Fiberboard

Figure 10. Closing the material cycle of the sugarcane industry in Egypt [31].

systems in the sugarcane industry the sugar harvest and the milling stage. The authors suggested several solutions to close the loop of the these system as follows: 1) produce silage from green tops of sugar harvest, 2) compost from the dry leaves, 3) produce good quality compost or organic fertilizer out of the bagasse in combination with the filter cake/mud, and 4) produce silage out of bagasse.

\section{Status of Egypt}

One of the major problems in Egypt is poor industrial hazardous waste management. Most of the industries follow the cradle-to grave approach described earlier and the problem is that these highly polluted wastes are mismanaged. There are no accurate measures of the annual industrial hazardous waste generated in Egypt. However, based on Basel Convention, Country Fact Sheet, Egypt, the total amount of hazardous wastes generated is 200,000 ton/year. Moreover, 6.2 million tons of industrial waste is generated annually [32]. According to El-Haggar, industrial waste is usually either landfilled or incinerated [2]. As ex- 
plained earlier, these two methods require high capital and running cost. Also if they are not properly managed they could result into serious environmental damages.

Additionally, industries generated highly polluted wastewater composed of organic maters, heavy metals, as well as corrosive, toxic and microbial substances. Mashali et al., reported that there are 22 industrial liquid discharges to the Nile. They found that alluvial clay soil of North Nile Delta is rich in heavy metals, including $\mathrm{Co}, \mathrm{Cr}, \mathrm{Cu}, \mathrm{Ni}$ and $\mathrm{Zn}$. They also stated that the around 12 million $\mathrm{m}^{3} /$ year of effluent are discharged into the river Nile at Helwan city [33].

This water is usually directly pumped for irrigation (without any treatment) or as a source of water for drinking. This resulted into deterioration of quality of water and food. Also, people take sludge and directly use it as a fertilizer for agriculture, which causes a lot of health problems.

Some investments and efforts are made to build treatment the industrial wastewater. The first treatment facility for hazardous waste in Egypt was made in Alexandria in 2000 under the Naserya project, a joint effort between EEAA, Governorate of Alexandria and the Ministry for Foreign Affairs of Finland. The project consists of a landfill of $14,000 \mathrm{~m}^{2}$ area, a physical-chemical treatment plant for inorganic liquid hazardous waste and a solidification unit, inorganic hazardous waste storage area and organic hazardous waste transfer station. The annual capacity of the physical-chemical treatment plant is $4000 \mathrm{~m}^{3}$ [34]. However, conventional treatment plants require high capital cost as well as running cost.

It is also worth reporting two important attempts of applying cleaner production and sustainable industrial concepts and practices in Egypt. The first example is the Environmentally Friendly New Industrial Cities Program (NICs). This program was developed by the Egyptian Ministry of State for Environmental Affairs in 1998. The main goal of this program is to encourage collaboration between different stakeholder including the government, industries and community to increase productivity, industrial activities as well as offer job opportunities to residents without having any negative impact on the local resources and surrounding environment. The first phase (from 1998 to 2000) was targeting $10^{\text {th }}$ of Ramadan City and $6^{\text {th }}$ of October City. An industrial city is qualified as being "Environmentally Friendly" if at least $90 \%$ of the operating facilities comply with regulation of law 4/1994 [34]. Although the program has attracted wide attention at the beginning, the industries stopped complying with regulations after a few years.

Another project called Integrated Industrial Solid Waste Management (IISWM) was launched by the Egyptian Environmental Affairs Agency (EEAA) in collaboration with the EU LIFE Third Countries in 2001. The goal of this project is to develop an integrated plan or action plan for the management of industrial solid waste that can replace the improper solid waste management practices. This project was first implemented on $6^{\text {th }}$ of October City that can then serve as model for other industrial zones. This project consisted of first gathering data about 
industrial facilities, their solid waste collection mechanisms and disposal techniques and an inventory was developed containing 700 industrial facilities. Then an action plan was developed following the European Commission's standards as well as tender documents for the Industrial Solid Waste Management System of $6^{\text {th }}$ of October. State of the art industrial practices were selected for industrial solid waste treatment and disposal, methods of waste exchange and minimization and Life Cycle Assessment for several industrial products was performed. The most important outcome of IISWM project was the waste exchange program. These outcomes were publicized via seminars, workshops and through their EEAA website. However, the waste exchange program was not successful and stopped [34].

Sustainable industrial practices are in still in the experimental phase in Egypt. The major problem facing the spread of sustainable industrial concepts can be summarized as follows: 1) lack of reinforcement of laws and regulations related to environment, 2) lack of collaboration, communication and trust between different stakeholders (i.e. different industries, government and society), 3) lack of awareness and information of all stakeholders, indeed they do not see any benefit from networking.

\section{Conclusion}

The environmental tragic situation facing the industrial areas, especially in developing countries like Egypt, associated with disposing industrial waste according to cradle-to-grave concept via incineration and/or landfilling cannot be ignored. It is vital to close the loop of flow of material and to stop depletion of natural resources. The solutions to reach zero-pollution in the industrial sector require innovative ideas that apply the concepts of cradle-to-cradle, industrial ecology and/or environmentally balanced industrial complexes. These solutions also need a strong collaboration between environmentalists, industries, and business community, society and policy makers. Indeed, product manufacturers need to develop original techniques that use less material which can be re-used or recycled. The government needs to develop a strong database of all industrial activities in the country and share them with all manufacturers to find innovative solutions to match different industries productions to use each other wastes. These ideas need to be studied by academic institutions and research centers. The government needs to support these concepts by developing and reinforcing strict rules and/or laws that prohibit landfilling and incineration to force manufacturers to implement more novel pollution prevention approaches. It is imperative that the proposed solutions utilize available and obtainable technologies and are compatible with social and environmental norms of each country.

\section{References}

[1] El-Haggar, S.M. (2009) Industrial Solid Waste Utilization and Disposal. In: Nemrow, N., Agardy, F., Sullivan, P. and Salvato, J., Eds., Environmental Engineering. Environmental Health and Safety for Municipal Infrastructure, Land Use and Planning, and Industry, 6th Edition, John Wiley \& Sons Inc., Hoboken, 1-81. 
https://doi.org/10.1002/9780470432822.ch1

[2] El-Haggar, S.M. (2007) Sustainable Industrial Design and Waste Management: Cradle-to-Cradle for Sustainable Development. Elsevier Academic Press, Cambridge, MA.

[3] Tammemagi, H. (1999) Waste Crisis: Landfills, Incinerators, and the Search for a Sustainable Future. Oxford University Press, Oxford.

[4] Nemerow, N.L. (1995) Zero Pollution Industry: Waste Minimization through Industrial Complexes. John Wiley-\& Sons, Hoboken.

[5] O’Riordan, T. (2004) Environmental Science, Sustainability and Politics. Transactions of the Institute of British Geographers, 29, 234-247. https://doi.org/10.1111/j.0020-2754.2004.00127.x

[6] Tudor, T., Adam, E. and Bates, M. (2007) Drivers and Limitations for the Successful Development and Functioning of EIP (Eco-Industrial Parks): A Literature Review. Ecological Economics, 61, 199-207. https://doi.org/10.1016/j.ecolecon.2006.10.010

[7] Dunn, B. and Steinemann, A. (1998) Industrial Ecology for Sustainable Communities. Journal of Environmental Planning and Management, 41, 661-672. https://doi.org/10.1080/09640569811353

[8] Brundtland, G.H. and Khalid, M. (1987) World Commission on Environment and Development: Our Common Future. Oxford University Press, New York.

[9] McDonough, W. and Braungart, M. (2002) Cradle to Cradle: Remarking the Way We Make Things. North Point Press, New York.

[10] Glavic, P. and Lukman, R. (2007) Review of Sustainability Terms and Their Definitions. Journal of Cleaner Production, 15, 1875-1885.

https://doi.org/10.1016/j.jclepro.2006.12.006

[11] El-Haggar, S.M. (2015) Sustainability and Innovation: The Next Global Industrial Revolution. The American University Press, Cairo.

[12] Frosch, R.A. and Gallopoulos, N.E. (1989) Strategies for Manufacturing. Scientific American, 261, 144-152. https://doi.org/10.1038/scientificamerican0989-144

[13] White, R. (1994) The Greening of Industrial Ecosystems (Allenby, B.R. and Richards, D.J., Eds.). National Academy Press, Washington DC.

[14] Allenby, B. (2006) The Ontologies of Industrial Ecology? Progress in Industrial Ecology, An International Journal, 3, 28-40. https://doi.org/10.1504/PIE.2006.010039

[15] Frosch, R. (1992) Industrial Ecology: A Philosophical Introduction. Proceedings of the National Academy of Sciences of the United States of America, 89, 800-803. https://doi.org/10.1073/pnas.89.3.800

[16] O’Rourke, D., Connelly, L. and Koshland, C. (1996) Industrial Ecology: A Critical Review. International Journal of Environment and Pollution, 6, 89-112.

[17] Lowe, H. (1993) Industrial Ecology—An Organizing Framework for Environmental Management. Environmental Quality Management, 2, 73-85.

https://doi.org/10.1002/tqem.3310030108

[18] Tibbs, H. (1992) Industrial Ecology-An Agenda for Environmental Management. Pollution Prevention Review, 167.

[19] Kim, S.J. (2002) Korean Waste Management and Eco-Efficient Symbiosis-A Case Study of Kwangmyong City. Clean Technologies and Environmental Policy, 3, 371382. https://doi.org/10.1007/s10098-001-0124-9

[20] Van Berkel, R., van Beers, D. and Bossilkov, A. (2006) Regional Resource Synergies for Sustainable Development: The Case of Kwinana. Materials Forum, 30, 176-187.

[21] Veiga, L.B.E. and Magrini, A. (2009) Eco-Industrial Park Development in Rio de Ja- 
neiro, Brazil: A Tool for Sustainable Development. Journal of Cleaner Production, 17, 653-661. https://doi.org/10.1016/j.jclepro.2008.11.009

[22] Ilgin, M.A. and Gupta, S.M. (2010) Environmentally Conscious Manufacturing and Product Recovery (ECMPRO): A Review of the State of the Art. Journal of Environmental Management, 91, 563-591. https://doi.org/10.1016/j.jenvman.2009.09.037

[23] Patnaik, R.P.G. (2015) Developing an Eco-Industrial Park in Puducherry Region, India-A SWOT Analysis. Journal of Environmental Planning and Management, 58, 976-996. https://doi.org/10.1080/09640568.2014.904768

[24] Peddle, M.T. (1993) Planned Industrial and Commercial Development in the United States: A Review of the History, Literature, and Empirical Evidence Regarding Industrial Parks and Research Parks. Economic Development Quarterly, 7, 107-124. https://doi.org/10.1177/089124249300700110

[25] Côté, R.P. and Cohen-Rosenthal, E. (1998) Designing Eco-Industrial Parks: A Synthesis of Some Experiences. Journal of Cleaner Production, 6, 181-188. https://doi.org/10.1016/S0959-6526(98)00029-8

[26] Cote, R. and Hal, J. (1995) Industrial Parks as Ecosystems. Journal of Cleaner Production, 3, 41-46. https://doi.org/10.1016/0959-6526(95)00041-C

[27] Chertow, M. (1997) The Source of Value: An Executive Briefing and Sourcebook on Industrial Ecology. Journal of Industrial Ecology, 1, 151-152. https://doi.org/10.1162/jiec.1997.1.2.151

[28] Gertler, N. (1995) Industrial Ecosystems: Developing Sustainable Industrial Structures thesis. Technology and Policy Program, Engineering Systems Division, Massachusetts Institute of Technology, Cambridge, MA.

[29] Nemerow, N.L. and Dasgupta, A. (1986) Environmentally Balanced Sugar Refinery Complex. Journal of Environmental Engineering, 112, 229-235. https://doi.org/10.1061/(ASCE)0733-9372(1986)112:2(229)

[30] Nemerow, N.L. (2007) Industrial Waste Treatment: Contemporary Practice and Vision for the Future. Elsevier Inc., Oxford.

[31] Nakhla, D.A. and El Haggar, S. (2014) A Proposal to Environmentally Balanced Sugarcane Industry in Egypt. International Journal of Agricultural Policy and Research, 2, 321-328.

[32] Zaki, T. and Khayal, A. (2010) Country Report on the Solid Waste Management in Egypt. The Regional Solid Waste Exchange of the Information Expertise Network in Mashreq and Maghreb Countries.

[33] Mashali, S., El-Essawi, T., Youssif, T. and Hafz, O. (2009) Effect of Different Industrial Wastes on Soil Quality at Different Locations of Egypt.

[34] Sakr, D., Baas, L., El-Haggar, S. and Huisingh, D. (2011) Critical Success and Limiting Factors for Eco-Industrial Parks: Global Trends and Egyptian Context. Journal of Cleaner Production, 19, 1158-1169. https://doi.org/10.1016/j.jclepro.2011.01.001 
Submit or recommend next manuscript to SCIRP and we will provide best service for you:

Accepting pre-submission inquiries through Email, Facebook, LinkedIn, Twitter, etc. A wide selection of journals (inclusive of 9 subjects, more than 200 journals)

Providing 24-hour high-quality service

User-friendly online submission system

Fair and swift peer-review system

Efficient typesetting and proofreading procedure

Display of the result of downloads and visits, as well as the number of cited articles Maximum dissemination of your research work

Submit your manuscript at: http://papersubmission.scirp.org/

Or contact jep@scirp.org 